\title{
The effect of slope gradient on plant cover index (C) of faba bean crops grown on loess soil
}

\author{
KAZIMIERZ KLIMA, MACIEJ CHOWANIAK \\ Department of General Soil and Plant Cultivation, Hugo Kołłątaj Agricultural University in Cracow
}

\begin{abstract}
The effect of slope gradient on plant cover index $(C)$ of faba bean crops grown on loess soil. In a period from 2002 to 2005, a single-element field experiment was conducted at the Experimental Station in Mydlniki near Cracow. The field top soil was a brown loess-derived soil. The main objective of the experiment was to determine the effect of slope gradient on the plant cover index $\mathrm{C}$ of small bean crops. The impact of two slope gradients ( $9 \%$ and $16 \%$ ) on the level of surface soil losses was studied, as was, in the experiment, the amount of surface soils exported from fallowed plots and from the plots grown with faba beans. The experiment on the impacted $22.13 \times 1.87 \mathrm{~m}$ plots was four times repeated in each gradient zone. It was stated that the plant cover index $\mathrm{C}$ was 0.187 in the case of faba beans grown and cropped on the slopes showing a $16 \%$ gradient, and, it was 0.154 on the slopes with a $9 \%$ gradient. The impact of the total area of plant top ends expressed by an index called LAI (Leaf Area Index) on the value of index $\mathrm{C}$ is described by exponential functions, i.e. in the case of slope gradient being 16\%: $y=0.6081 e^{-0.6016 x}$, and the slope gradient of $9 \%: y=0.5447 \mathrm{e}^{-0.6341 x}$.
\end{abstract}

Key words: Leaf Area Index, C index, runoff plots, soil erosion, slope gradient, small bean.

\section{INTRODUCTION}

Water erosion threat connected with both the soil splash and the surface runoff constitutes a serious problem, especially on agriculturally utilized soils. Proper land management plays an essential part in reducing negative results of water erosion, in particular, when soil-protecting properties of plants are taken into consideration and utilized. In many research aiming at the determination of areas endangered by water erosion, various models are applied to predict a process and progress of water erosion. Also, a multinomial equation USLE (Universal Soil Loss Equation) (Wischmeier and Smith 1978) RUSLE is often applied. In the model mentioned, the soil-protecting effectiveness of cover plant is identified by a plant cover index (C). Regarding the strongly regional character of $\mathrm{C}$ index, it is necessary to determine its value for many plants cultivated under varying soil and climatic conditions in our country. This fact gave rise to initiate a research in this domain.

The objective of the research was to determine the effect of slope gradient on the plant cover index values $(\mathrm{C})$ of the small beans crops.

\section{METHODS}

In a period from 2002 to 2005 , a single-element field experiment was conducted on a brown, loess-derived soil, at the Experimental Station in Mydlniki near 
Cracow, run by the Department of General Soil and Plant Cultivation, Agricultural University of Cracow. The tilth top soil contained, on average, $49.2 \%$ of dust, and $6 \%$ of colloidal clay. The soil erodibility indicator was represented by the ratio: dust fraction to colloidal clay fraction, and in the research, this indicator was 8.2. The $\mathrm{pH}$ level of the soil, measured in the soil solution, was 5.9.

Furthermore, the impact was investigated of two slope gradients: $9 \%$ and $16 \%$, on the quantity of surface wash carried out from the fallowed plots and the plots sown with small beans. Plots sized $22.13 \times 1.87 \mathrm{~m}$, regarded the standard in measuring the surface runoff (Józefaciuk and Józefaciuk 1996) were 4 times repeated in each zone of the given slope. The size of surface runoff was measured using Słupik plastic bags (Słupik 1975). The Słupik catcher consisted of a foil bag fixed on a metal rack. The catchers were installed on the bottom edge of each plot. The catchers were emptied after each rainfall or after a snow-melting season generating a surface runoff.

Next, to determine the intensity of surface wash, 1 litre of water with suspended matters was filtered using a medium hard filter, then, the sediment was dried at a temperature of $105^{\circ} \mathrm{C}$. The filters were cooled in a desiccator and weighed on an electronic analytical balance with a $0.0001 \mathrm{~g}$ resolution. The surface area of plant superstructures was measured using a LAI-meter (which determined the value of 'LAI' i.e. leaf area index), manufactured by the "Sun Scan Canopy Analysis System" Company.

The meteorological conditions in the years from 2002 to 2005 varied. The annual totals of rainfalls during the research period ranged from 566.5 to $757.3 \mathrm{~mm}$ (Fig. 1). The totals of rainfalls during the vegetation period ranged from 352.1 to $558.6 \mathrm{~mm}$ (Fig. 1). With regard to rainfall levels and under the criteria of evaluating the years and vegetation seasons as determined by Kaczorowska (1962), the entire year 2002 was wet including the vegetation season, the other years covered by the experiment were considered dry years and the vegetation seasons were found to be average. The annual mean temperature was between 6.8 and $8.2^{\circ} \mathrm{C}$. During the research performed, 4 thaw periods were recorded and 20 rainfalls generating the surface-wash.

\section{THE RESULTS AND DISCUSSION}

On the basis of the research results obtained, it was found that the average quantities of surface rainwash were as follows: $9293 \mathrm{~kg} \cdot \mathrm{ha}^{-1}$ on the fallowed plots with a $16 \%$ slope gradient; $6472 \mathrm{~kg} \cdot \mathrm{ha}^{-1}$ on the plots with a $9 \%$ slope gradient; and on plots sown with small beans: $1734 \mathrm{~kg} \cdot \mathrm{ha}^{-1}$ as for a $16 \%$ slope gradient, and $995.6 \mathrm{~kg} \cdot \mathrm{ha}^{-1}$ as for a $9 \%$ gradient. Other research results (Klima 2007) confirm that the average quantities of wash on plots with small beans grown on them are similar to those obtained in the experiment and research accomplished and presented in this paper.

In the research represented in this paper, for the whole vegetation period of small beans grown on the plots with two different slope gradients, the plant cover index (C) was 0.187 for the slope gradient of $16 \%$, and 0.154 for the slope gradient of $9 \%$. The highest values of $\mathrm{C}$ index were recorded during the initial 
a)

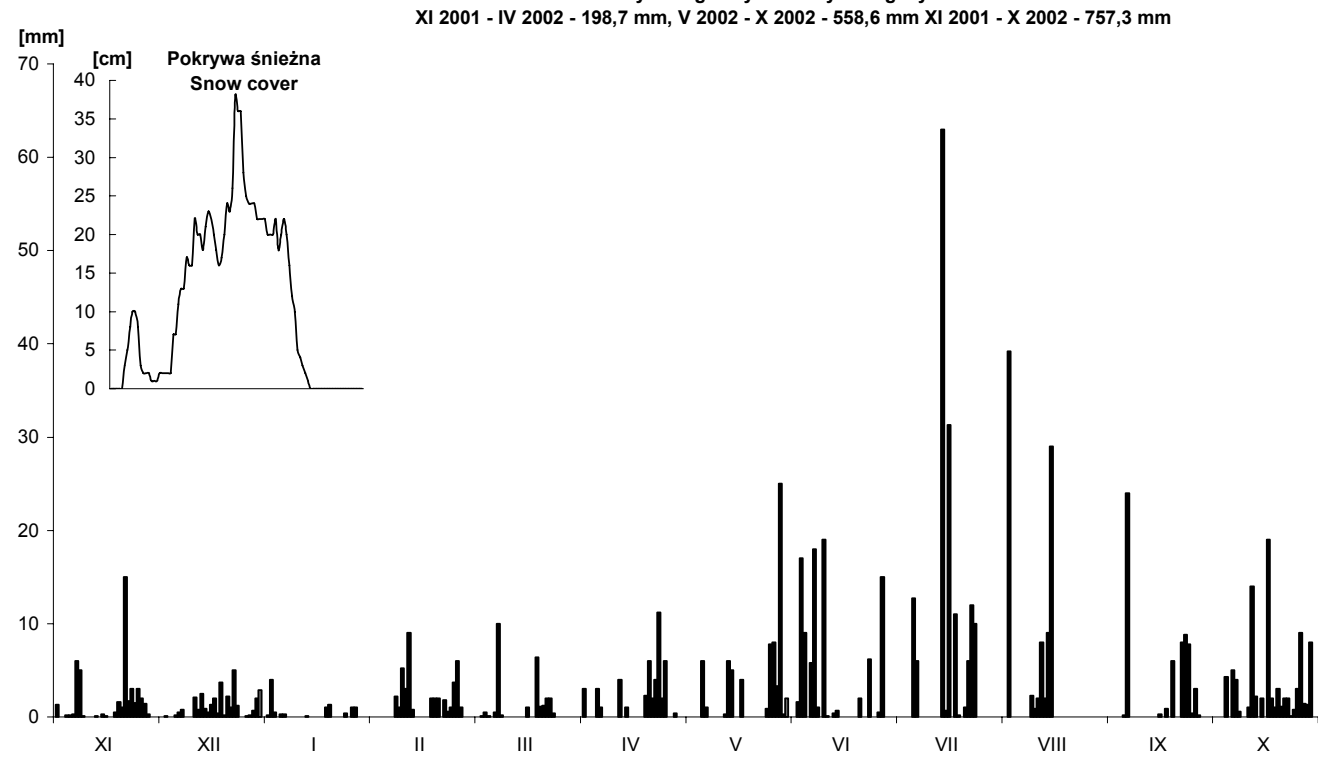

b)

[mm]

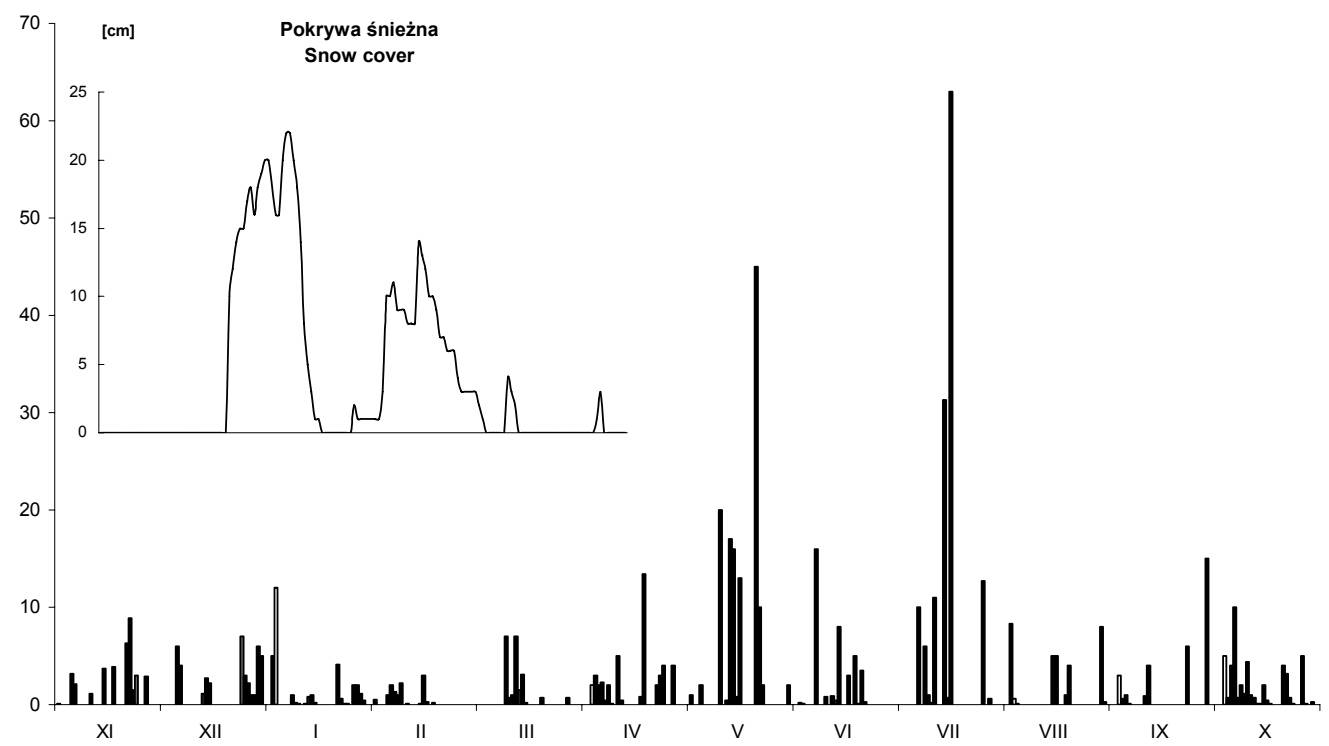

FIGURE 1. Rainfall (mm) and snow cover in the hydrologic years: 2002 (a), 2003 (b), 2004 (c), and $2005(d)$ 
c)

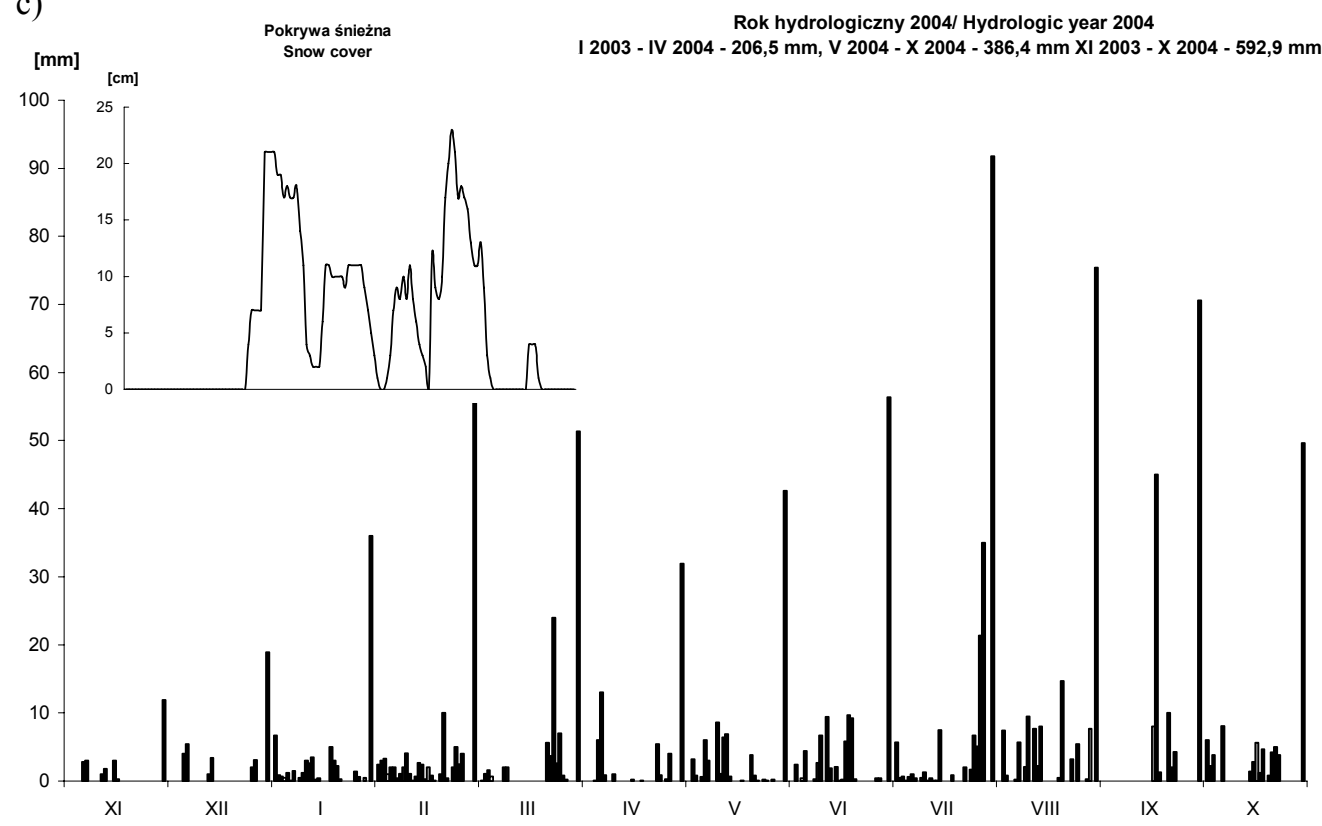

d)

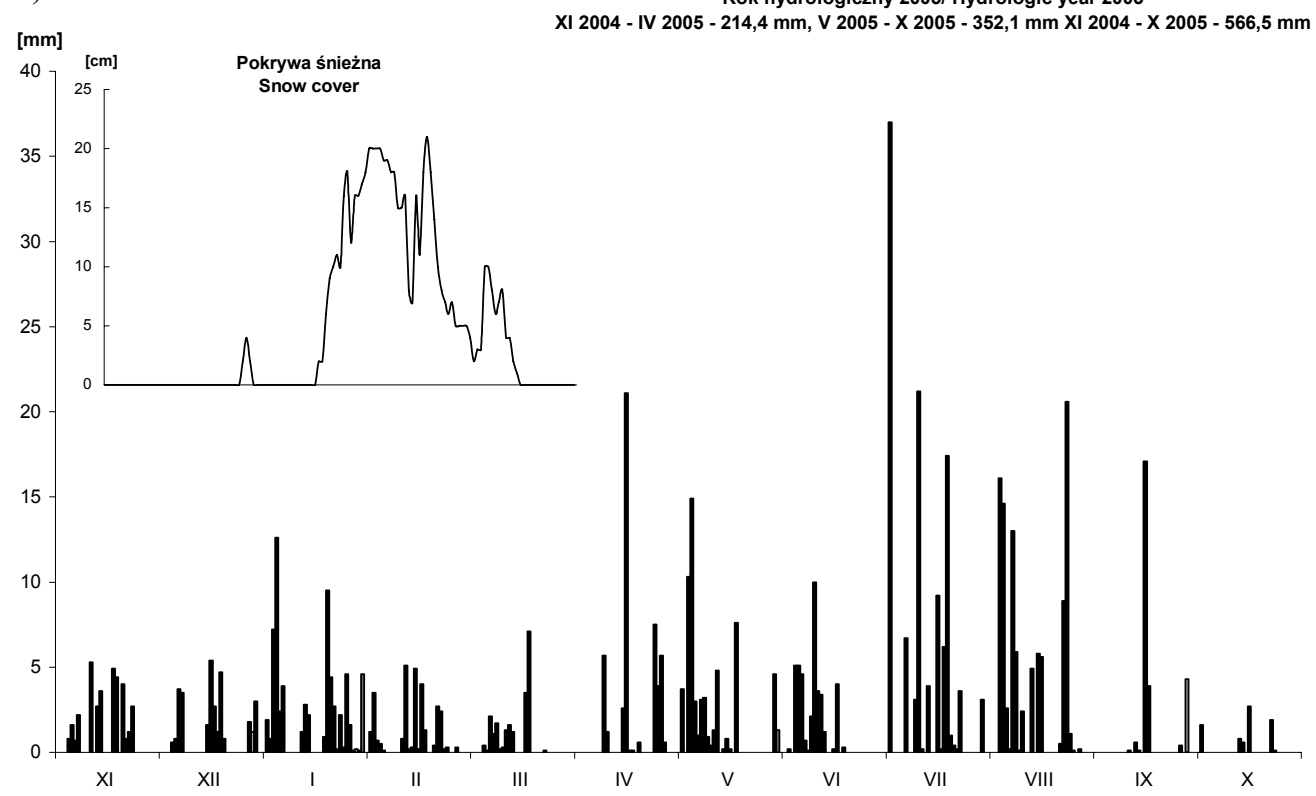

FIGURE 1 (continued) 
phases of plant growing, and the lowest - when the entire plot was covered by small beans (Tab. 1). In the literature available, no information was found on the plant cover index referring to small bean crops. Thus, it can be stated that the results presented in this paper constitute one of the very first attempts to determine the value of $\mathrm{C}$ index for small bean crops using field experiments and their results obtained under specific climatic and soil conditions as present in Southern Poland.
The periods as above were assumed according to Schwertmann et al. (1987).

The anti-erosive (soil-protecting) properties of small beans improved along with the increase in the value of $\mathrm{C}$ index of small beans (Figs 2, 3). Klima (2000) also found that the least values of surface wash occurred during the phases when the plants (small beans) grew, and when their Leaf Area Index (LAI) values were the highest. According to Rejman (2006), the scale of water erosion is considerably related to the length of the

TABLE 1. Values of C index from the experiments

\begin{tabular}{|c|c|c|c|c|c|c|c|}
\hline \multirow[b]{2}{*}{ Slope gradient } & \multicolumn{6}{|c|}{ Periods of planting small beans planting and their growing } & \multirow[b]{2}{*}{ Average } \\
\hline & $\begin{array}{c}\text { from } \mathrm{PGO} \\
\text { to } \mathrm{s}\end{array}$ & $\begin{array}{l}\text { from } \mathrm{s} \\
\text { to } 10 \%\end{array}$ & $\begin{array}{c}\text { from } 10 \% \\
\text { to } 50 \%\end{array}$ & $\begin{array}{c}\text { from } 50 \% \\
\text { to } 75 \%\end{array}$ & $\begin{array}{c}\text { from } \\
75 \% \text { to } z\end{array}$ & $\begin{array}{l}\text { from } z \\
\text { to } P G\end{array}$ & \\
\hline $16 \%$ & 0.49 & 0.72 & 0.63 & 0.20 & 0.11 & 0.30 & 0.19 \\
\hline $9 \%$ & 0.46 & 0.62 & 0.49 & 0.18 & 0.09 & 0.28 & 0.15 \\
\hline
\end{tabular}

- PGO to $\mathrm{s}$ - period starting when previous plants are skimmed off the plot until new plants are sown;

- from $\mathrm{s}$ to $10 \%$ - period starting when small beans are sown until they cover $10 \%$ of the entire plot surface;

- from $10 \%$ to $50 \%$ - period when the cover of small beans on the plot is between $10 \%$ and $50 \%$;

- from $50 \%$ to $75 \%$ - period when the cover of small beans on the plot is between $50 \%$ and $75 \%$;

- from $75 \%$ to $\mathrm{z}$ - period starting when the cover of small beans on the plot is $75 \%$ until the harvest;

- from $\mathrm{z}$ to $\mathrm{PG}$ - period from the harvest to skimming off.

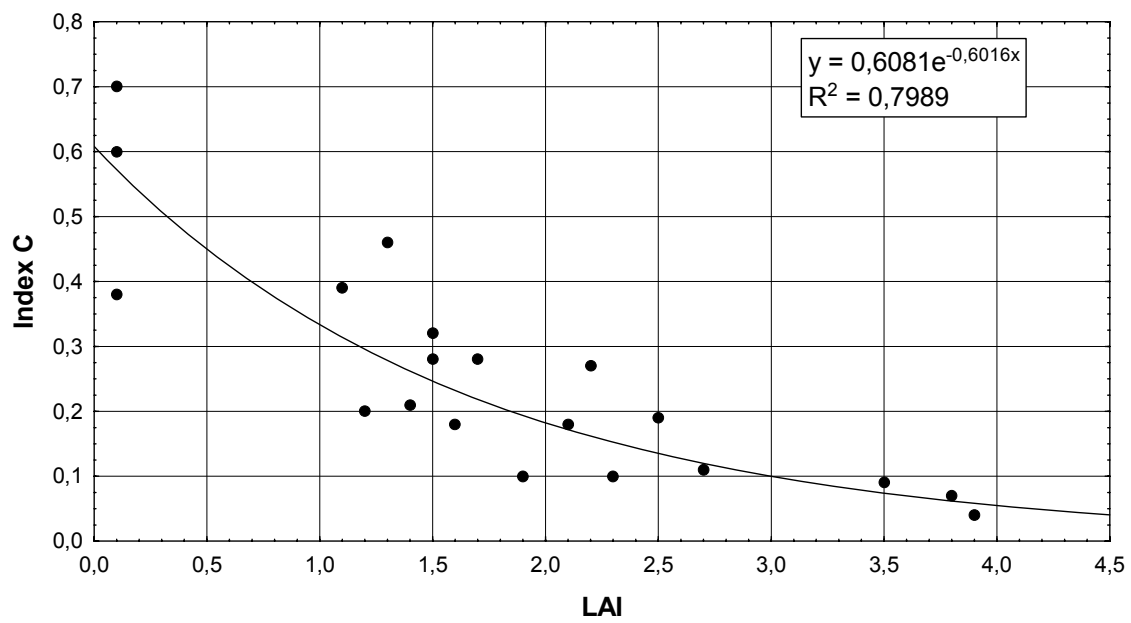

FIGURE 2. The relationship between $\mathrm{C}$ index and LAI index when the slope gradient is $16 \%$ 


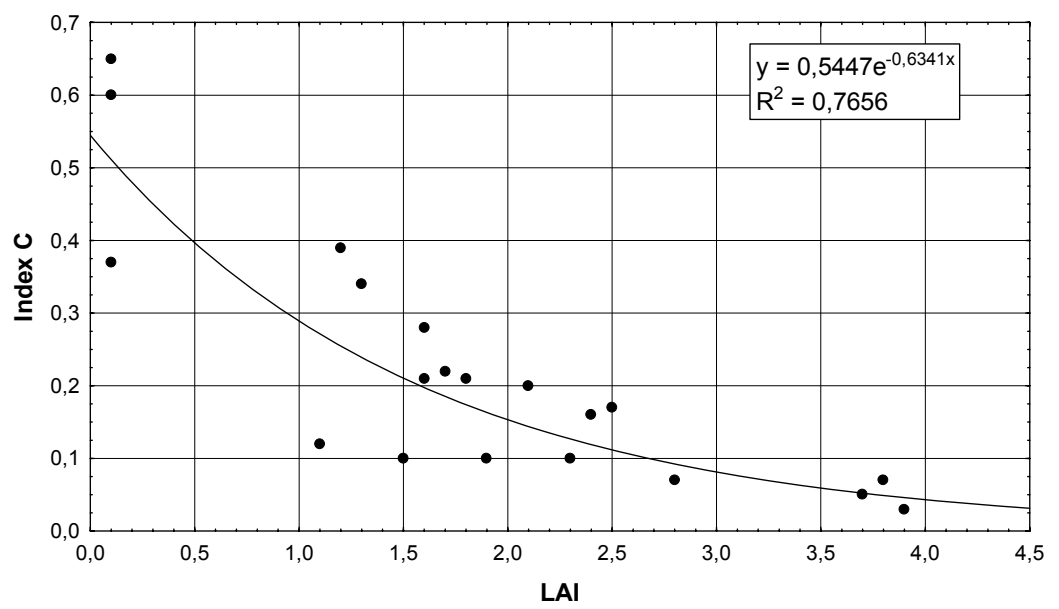

FIGURE 3. The relationship between C index and LAI index when the slope gradient is $9 \%$

vegetation season, to the erosiveness of rain, and to the plant development phase, thus, to the size of plant cover on the plot/field surface. In this particular study, the dependence between the value of $\mathrm{C}$ index and the growing surface of plant superstructures is described by the following exponential functions:

$y=0.6081 \mathrm{e}^{-0.6016 x}$ (for the slope gradient of $16 \%$ ) (Fig. 3);

$y=0.5447 e^{-0.6341 x}$ (for the slope gradient of $9 \%$ ).

Similarly to the studies performed by Rejman and Brodowski (1999), the statistical analysis performed showed that the value of $C$ index could be properly predicted on the basis of value of the Leaf Area Index using the exponential function.

\section{CONCLUSIONS}

1. Referring to the 4-year period of the research accomplished, the value of index (C) was 0.187 for the slopes with a $16 \%$ gradient, and 0.154 for the slopes with a $9 \%$ gradient.
2. The value of $C$ index of small beans showed rising soil-protecting properties of this plant along with the increase in the surface of its superstructure.

3. The relationship between the value of $\mathrm{C}$ index and the growing surface of plant superstructure is described by the following exponential functions: $y=0.6081 e^{-0.6016 x}$ (for the slope gradient of $16 \%$ ) and $y=0.5447 e^{-0.6341 x}$ (for the slope gradient of $9 \%$ ).

\section{REFERENCES}

JOZEFACIUK A., JÓZEFACIUK CZ. 1996: Mechanizm i wskazówki metodyczne badania procesów erozji. Wyd. Państwowa Inspekcja Ochrony Środowiska, Warszawa. s. 1-138.

KACZOROWSKA Z. 1962: Opady w Polsce w przekroju wieloletnim. Prace Geogr. IG PAN, 33, 1-107.

KLIMA K. 2000: Produkcyjność i przeciwerozyjna skuteczność płodozmianów w warunkach górskich południowo zachodniej części Beskidu Niskiego. Wyd. AR w Krakowie. 1-96.

KLIMA K. 2007: Glebochronność roślin uprawianych $\mathrm{w}$ warunkach górskich. Problemy Zagospodarowania Ziem Górskich, 131-37. 
REJMAN J., BRODOWSKI R. 1999: Ocena natężenia erozji wodnej w uprawie buraka cukrowego na glebie lessowej. Acta Agrophysica, 23, 133-142.

REJMAN J. 2006: Wpływ erozji wodnej i uprawowej na przekształcanie gleb i stoków lessowych. Wyd. Instytut Agrofizyki PAN, Lublin. $1-89$.

SCHWERTMANN U. VOGL W., KAINZ M. 1987: Bodenerosion durch Wasser: Vorhersage des Abtrags und Bewertung von Gegenmaßnahmen. Ulmer, Stuttgart, 1-64.

SŁUPIK J. 1975: Conditions of Infiltration and Surfach Run-off in the Sant Catchment Basin. Biul. De l'Academie Pol. des Scien., ser. des Scien. de la Terre, vol 23, no 3-4, 233-236.

WISHMEIER W.H., SMITH D.D. 1978: Predicting rainfall erosion losses. USDA Agric. Handb. 537. U.S. Gov. Print. Office, Washington DC. $1-58$.

Streszczenie: Wplyw nachylenia stoku na wartości wskaźnika okrywy roślinnej $C$ w uprawie bobiku na glebie lessowej. Wskaźnik okrywy roślinnej i uprawy $\mathrm{C}$ znajduje swoje zastosowanie w modelach empirycznych m.in. USLE (Universal Soil Loss Equation), za pomocą których prowadzi się badania nad erozją gleb. Wskaźnik ten określa glebochronną skuteczność pokrywy roślinnej. Ze względu na silnie regionalny charakter wskaźnika $\mathrm{C}$ istnieje konieczność określenia jego wartości dla wielu roślin uprawianych $\mathrm{w}$ różnych warunkach klimatyczno-glebowych naszego kraju. Celem badań było określenie wpływu nachylenia powierzchni stoku na wartość wskaźnika okrywy roślinnej $\mathrm{C}$ w uprawie bobiku.

Eksperyment polowy przeprowadzono w latach 2002-2005 na glebie brunatnej wytworzonej z lessu w Stacji Doświadczalnej Katedry Ogólnej Uprawy Roli i Roślin zlokalizowanej w Mydlnikach koło Krakowa. Badano wpływ nachylenia stoku $9 \%$ i $16 \%$ na natężenie spłukiwania powierzchniowego na poletkach ugorowanych oraz obsianych bobikiem. Poletka o rozmiarach $22,13 \times$ $\times 1,87 \mathrm{~m}$ powtórzone były 4 -krotnie dla każdego nachylenia. W okresie badań wystąiły 4 okresy roztopowe oraz 20 opadów atmosferycznych wywołujących spłukiwanie powierzchniowe. Dla 4-letniego okresu badań wartość wskaźnika (C) przy nachyleniu $16 \%$ wyniosła 0,187 , a przy nachyleniu $9 \% 0,154$. Wraz ze wzrostem powierzchni nadziemnych części bobiku wartość wskaźnika okrywy roślinnej C wykazywała większą glebochronność rośliny.

\section{MS. received April 2008}

Authors' address:

\section{Kazimierz Klima}

e-mail: rrklima@cyf-kr.edu.pl

Maciej Chowaniak

e-mail:maciejchowaniak@tlen.pl

Katedra Ogólnej Uprawy Roli i Roślin

Wydział Rolniczo Ekonomiczny

Uniwersytet Rolniczy im. Hugona Kołłątaja

w Krakowie

31-120 Kraków, Al. Mickiewicza 21

Poland 